\title{
The Expanding Earth: Indisputable Evidences of the Gobi Desert
}

\author{
Alexey Ju. Retejum \\ Lomonosov Moscow State University, Moscow, Russia \\ Email: aretejum@yandex.ru
}

How to cite this paper: Retejum, A.Ju. (2020) The Expanding Earth: Indisputable Evidences of the Gobi Desert. Open Journal of Geology, 10, 1-12.

https://doi.org/10.4236/ojg.2020.101001

Received: October 28, 2019

Accepted: December 28, 2019

Published: December 31, 2019

Copyright $\odot 2020$ by author(s) and Scientific Research Publishing Inc. This work is licensed under the Creative Commons Attribution International License (CC BY 4.0).

http://creativecommons.org/licenses/by/4.0/

\begin{abstract}
The most striking contrasts that are found on the continents in paleogeographic reconstructions of the end of the Mesozoic era are the occurrence on the place of the disappeared humid subtropics of the largest Gobi Desert in Eurasia with air temperatures falling below $50^{\circ}$ from the freezing point and annual precipitation totals at the level of $100 \mathrm{~mm}$. Science does not know the processes that can lead to a cooling of the atmosphere at $70^{\circ}$ and other equally radical changes in nature with a stable position of the blocks of the earth's crust in space. Changes in the environment of this magnitude can only be the result of land moving northward for a distance equal to about half the radius of the Earth. Titanosaurs, described by the remains in the Gobi deposits, had a body volume, which at modern gravity corresponds to a mass of 10 to 30 ton. However, animals with such a mass and such growth could not exist now. To create the necessary pressure in the vessels and provide energy to the body, Mongolian sauropods would need a heart of $2-3 \mathrm{~m}$ in diameter. Known types of muscle tissue are unable to maintain an elongated neck and head with a mass of more than a ton. The femur bones of four-legged dinosaurs had strength sufficient to move on land only animals weighing no more than 5 - 7 tons. The bones of giant bipedal dinosaurs at a constant gravitational field would have to be subjected to specific loads, several times greater than the bones of modern elephants, which is excluded. The natural conclusion about the action of a lesser gravity in the Mesozoic provides a solution to the mystery of the truly global spread in that era of bipedal mode of movement as the most energy efficient.
\end{abstract}

\section{Keywords}

Expanding Earth, Goby Desert, Cretaceous, Fossils, Giant Dinosaurs, Gravity, Atmospheric Circulation

\section{Introduction}

In January 1912, Alfred Wegener gave public lectures titled "Allocation of large 
forms of the Earth's crust (continents and oceans) on a geophysical basis" and "Horizontal movements of continents", introducing the audience to the reconstruction of the grandiose events of the collapse of the Pangaea. The hypothesis attracted a lot of attention, and the work devoted to it "The Origin of Continents and Oceans" [1] for 15 years has passed four editions in six languages. This can be explained not only by the revolutionary concept of mobilism itself, but also by the extremely broad formulation of the problem of global development. According to the author, "only through the synthesis of all the Earth Sciences, we can find the truth, that is, to restore the picture that best presents us with a set of known facts and therefore can claim the greatest probability. But even then we must constantly remember that every new discovery, to whatever branch of science it may belong, can change the conclusions we have drawn." Despite the success of the book, it was probably evident at the time that "not all researchers fully realized ... the importance of combining data from different fields of knowledge." It is impossible to speak about improvement of a cognitive situation and a century later.

Fairly well known the main features of the most interesting celestial body: the inclination of the rotation axis, its pear-shaped form with a massive, predominantly the marine part to the South of the equator, the differences between the Pacific and Continental hemispheres, close to the meridional orientation of the continents, the existence of thousands of kilometres of deep-sea rift marks stretching of the lithosphere, the similarity of topography on the earth's surface, etc., but the forces that created them are not a subject of active discussion in the modern literature. Thus, the Curie principle is violated, which aims at finding correspondences of symmetry and dissymmetry of bodies to existing causes. The exception is the relatively few publications of the followers of Ott Christoph Hilgenberg, who in the 20s of the XX century drew attention to the fact that the empirical data collected in the monograph "The Origin of Continents and Oceans" are much easier and better explained in the light of the hypothesis of the expansion of the Earth (Figure 1).

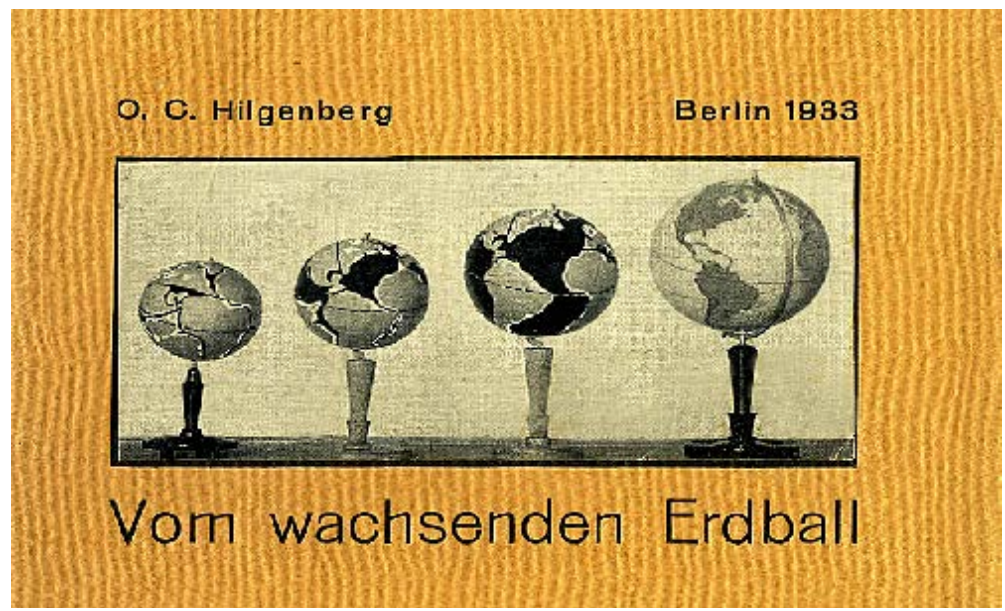

Figure 1. O.C. Hilgenberg's book about the growing globe [2]. 
After Hilgenberg's pioneering work, studies were conducted in different countries, the result of which was the accumulation of a huge number of geological, geophysical, geochemical, paleontological and other facts that clearly indicate an increase in the volume of the Earth [3]-[9].

The development of monitoring techniques in recent decades has provided new information supporting the idea of expanding the planet. This, in particular, the growth of gravity, the tendency to increase the distance between Eurasia, Africa and North America, offset the land masses to the North, the general rise of the Earth's surface, the sea level rise (fixed long before the period of climate warming), the drift of the Earth core from the southern hemisphere, the displacement of the Geographic North pole along the meridian $78^{\circ} \mathrm{W}$, along the border of the Continental and Pacific hemispheres and uneven decrease in the speed of rotation of the planet [10]. However, no obvious physiognomical signs of the transformation of the planet over hundreds of millions of years (for example wedge like continents and the prevalence of oceanic crust) or special observations (in the first place, with the force of gravity) still did not shake the old people's beliefs in the immutability of the volume of our celestial body. It is a question of a priori representations as proofs of constancy of the sizes of the Earth anybody never showed and could not show because of lack of means of long physical measurements.

From the point of view of the theory of paleogeography, it is important that in the picture of the world of the past, three phenomena of the Mesozoic era have not received a scientific explanation:

1) Extremely warm climate,

2) Gigantism and two-legged way of moving animals,

3) Distribution of landscapes of tropical and subtropical type far from the contemporary equator.

Specialization in modern science prevents the perception of many inconsistencies and contradictions, forcing to be satisfied with particular hypotheses.

For the improbable to become apparent, given the peculiarities of the psychology of perception of new knowledge, it is now required rather undeniable visual evidence than speculative evidence. Perhaps the most striking contrasts that are found on the continents in paleogeographic reconstructions is occurrence on the place of the disappeared humid subtropics of the largest Gobi Desert with air temperatures falling below $50^{\circ} \mathrm{C}$ and annual precipitation totals at the level of $100 \mathrm{~mm}$. Science does not know the processes that can lead to a cooling of the atmosphere at $70^{\circ}$ and other equally radical changes in nature with a stable position of the blocks of the earth's crust in space. Nevertheless, the maps created under the plate tectonics hypothesis show that the territories of Mongolia and Northern China 75 - 100 million years ago were at the same latitudes as they are now (Figure 2).

Changes in the environment of this magnitude can only be the result of land moving northward for a distance equal to about half the radius of the Earth. The 


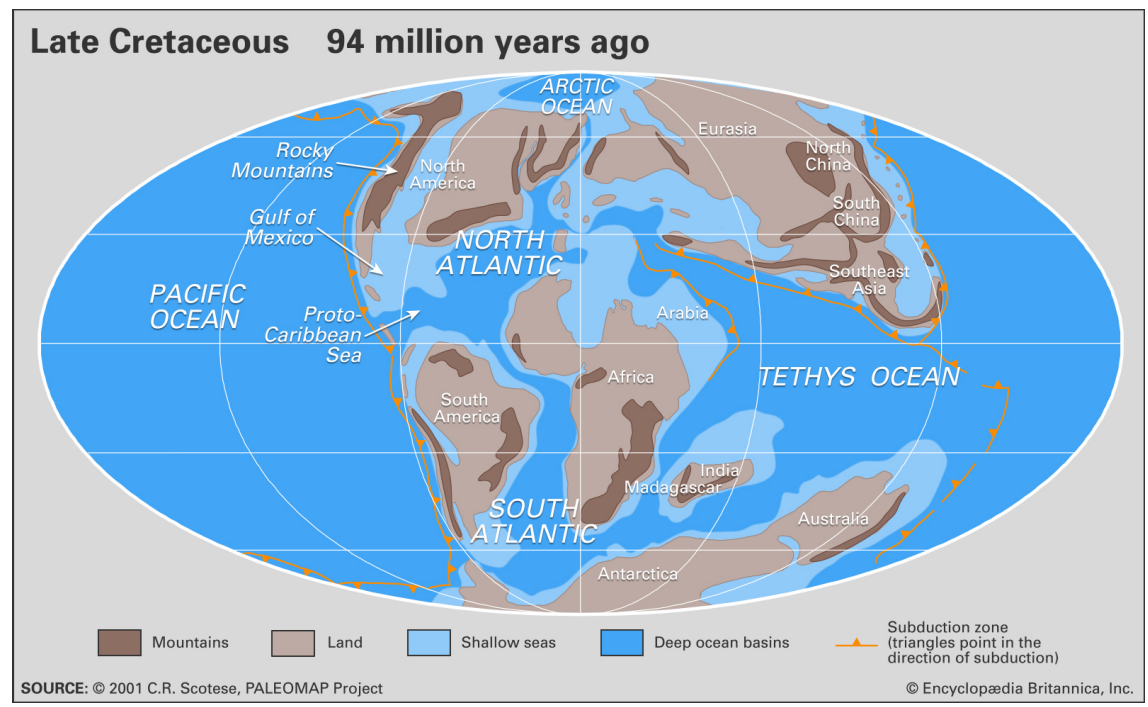

Figure 2. Paleogeographic reconstruction for the late Cretaceous. Source: [11].

study of Mongolia, free from any a priori ideas, allows us to solve a number of problems of the functioning of the biosphere millions of years ago.

\section{Mongolia and Northern China during the Cretaceous}

The territory of modern Gobi Desert is considered a real paleontological El Dorado. Mongolia and Northern China have no analogues in the world in terms of the wealth of fossil fauna [12] [13]. Thanks to the research that begun 100 years ago by the Director of the American Museum of Natural History, Roy Chapman Andrews and continued by various international groups of scientists, hundreds of new genera and even families of reptiles were discovered in the area, which in the Cretaceous period inhabited high-stemmed coniferous and deciduous forests of araucaria and sycamores, groves of gingko and palm-like bennettites, extensive meadows and swamps, deep rivers as wide as the Amur or the Yellow river and brackish lakes that may have had a connection with the sea [14] [15] [16].

In this realm stand out giant dinosaurs, the size and anatomy of the body which are in clear contradiction with the gravitational field of the Earth, if its current tension we would extrapolate into the distant past (see also [17] [18] [19]). Their group includes the herbivorous titanosaurs-quaesitosaurus (Figure 3) and nemegtosaurus (Figure 4), duckbill saurolophus (Figure 5), the therizinosaurs (Figure 6), omnivorous deinocheirus (Figure 7), and tarbosaurus-a close relative of the famous Tyrannosaurus (Figure 8).

Titanosaurs, described by the remains in the Gobi deposits, had a body volume, which at modern gravity corresponds to a mass of 10 to 30 ton. However, animals with such a mass and such growth could not exist now. First of all, gravity imposes severe restrictions on the blood supply to the brain and the entire body. The proportion of the heart is in power dependence on the total body weight, it increases with the increase in its size from $0.2 \%$ in a mouse and $0.3 \%$ in a rabbit to $0.9 \%$ in a horse and $1.2 \%$ in a giraffe. To create the necessary pressure 


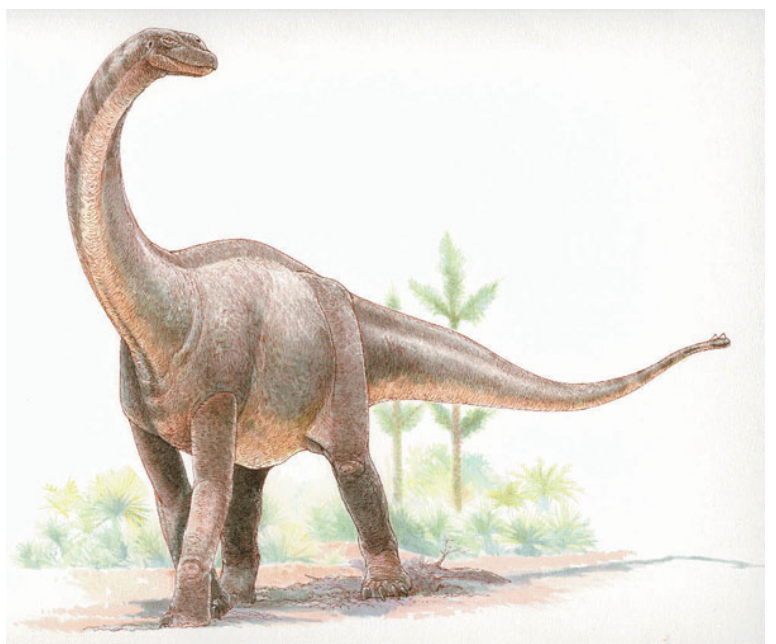

Figure 3. Quaesitosaurus (Quaesitosaurus orientalis), body length—about $20 \mathrm{~m}$ [20].

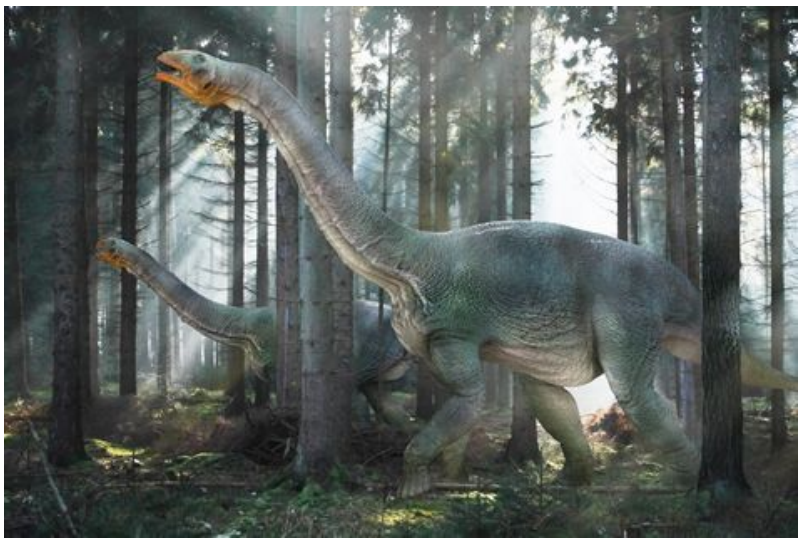

Figure 4. Nemegtosaurus (Nemegtosaurus mongoliensis), body length—up to $15 \mathrm{~m}$ [21].

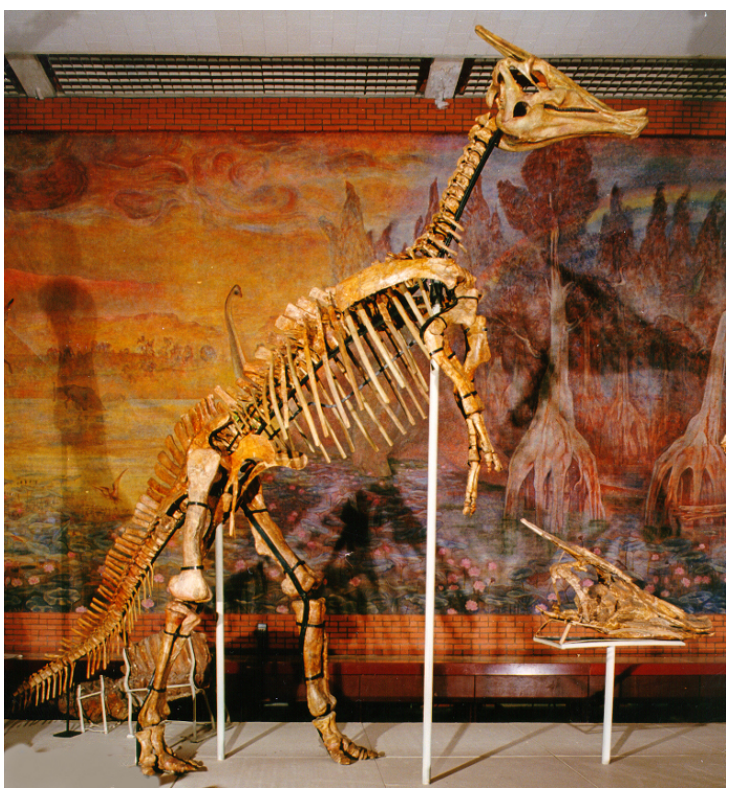

Figure 5. The skeleton of Saurolophus (Saurolophus angustirostris); an adult animal was a growth of about 5 - $6 \mathrm{~m} \mathrm{[22].}$ 


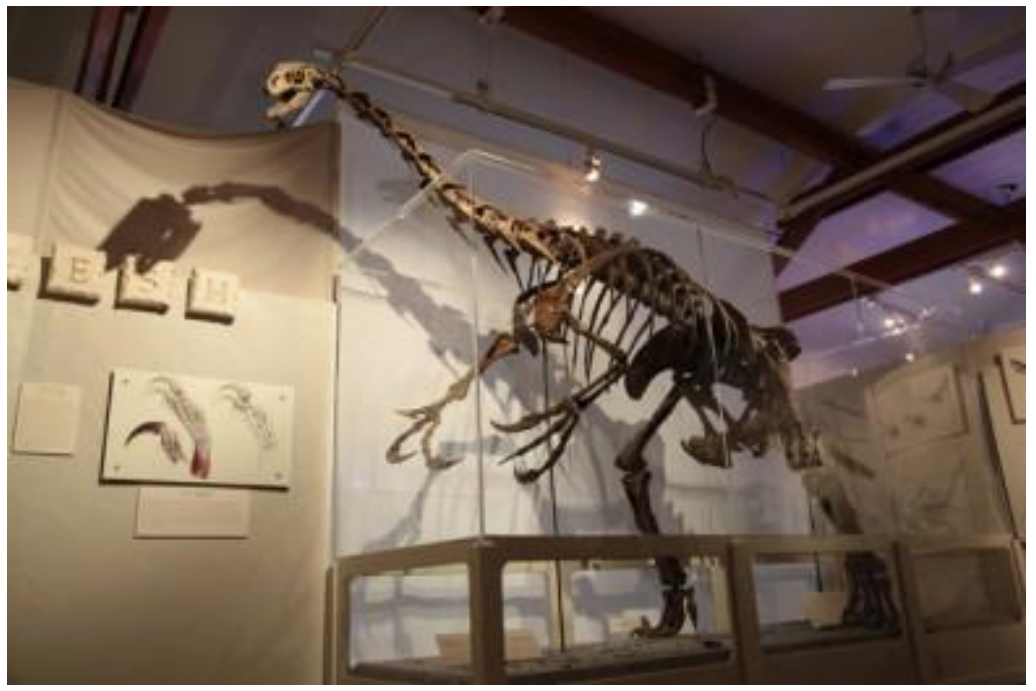

Figure 6. The skeleton of Therizinosaur (Therizinosaurus cheloniformis). The head of the reptile was at a height of $4-5 \mathrm{~m}$, the forelimbs were equipped with claws, reaching 1 $m$ in length [23].

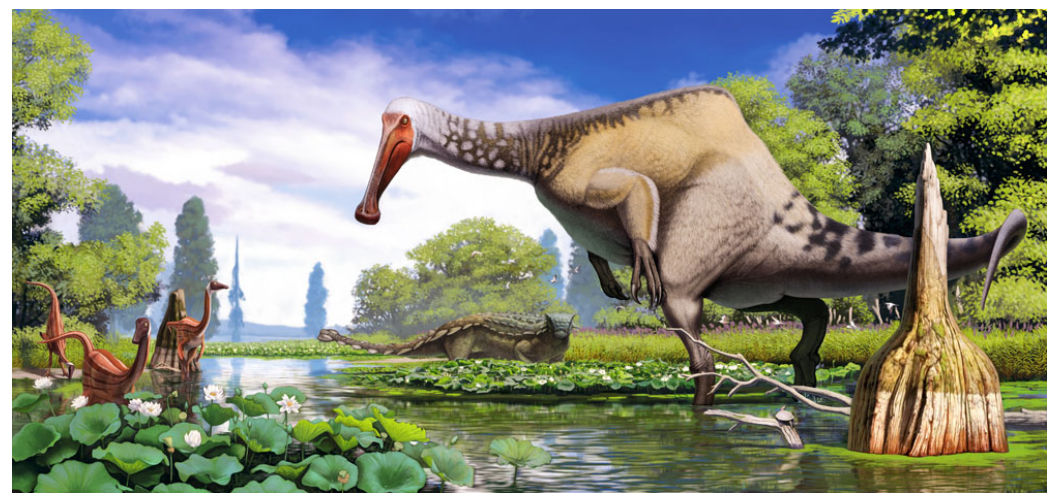

Figure 7. Deinocheirus (Deinocheirus mirificus), height 3 - $4 \mathrm{~m}$ [24].

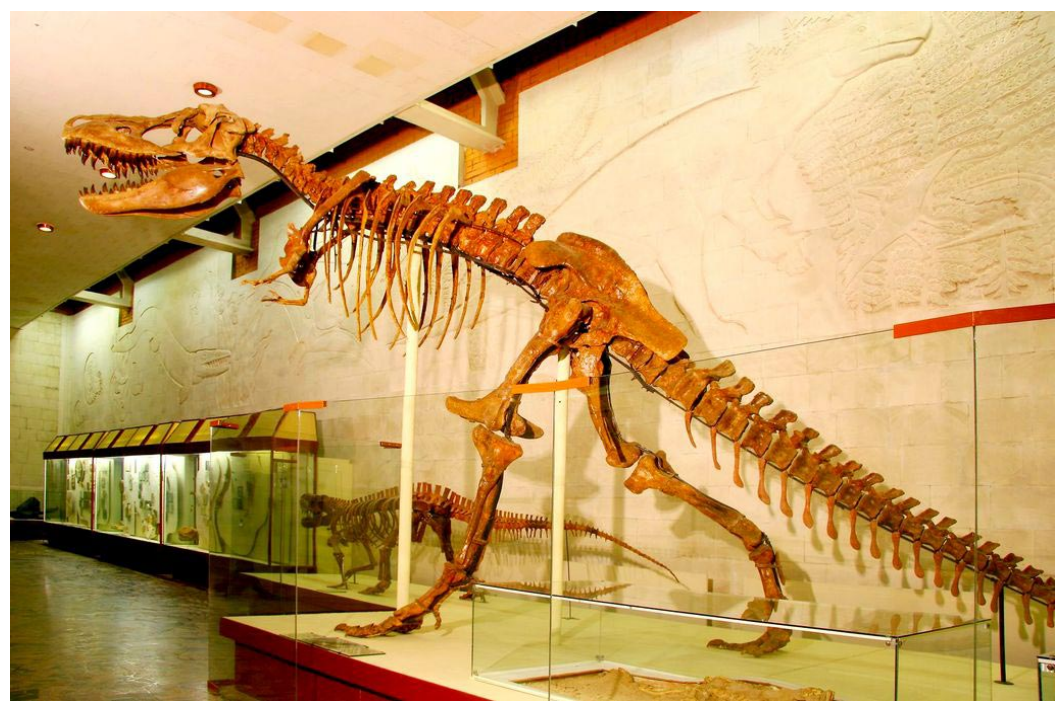

Figure 8. The skeleton of tarbosaurus (Tarbosaurus bataar). The largest predator was up to $12-14 \mathrm{~m}$ long and $3-4 \mathrm{~m}$ tall [22]. 
in the vessels and provide energy to the body, Mongolian sauropods would need a heart of disproportionately large size-at least $2-3 \mathrm{~m}$ in diameter. Further, known types of muscle tissue are unable to maintain an elongated neck and head with a mass of more than a ton, not to mention striking multi-meter tail on attacking predators. Finally, the femur bones of four-legged dinosaurs had strength sufficient to move on land only animals weighing no more than $5-7$ tons.

An even more clear picture of the limits of life are bipedal reptiles that have a load on the bone increases two or three times. The speed of their movement is a subject of acute debate in biomechanics, but the fact that they walked or ran for a very short time relied on one leg (Figure 9), the bones of which would have to withstand a huge impulse stress from the body, close in weight to the African elephant.

As we know, elephants do not run at all to avoid fractures, as a rule, rely on three legs at once, and only in extreme cases resort to amble, drawing on two legs.

Meanwhile, the limb bones of living elephants and bipedal giant dinosaurs differ little in diameter and, obviously, other characteristics (compare Figure 10 and Figure 8).

Thus, the bones of giant bipedal dinosaurs (with the possible exception of saurolophus with its near-water way of life) at a constant gravitational field would have to be subjected to specific loads, several times greater than the bones of modern elephants, which is excluded. The natural conclusion about the action of a lesser gravity in the Mesozoic provides a solution to the mystery of the truly global spread in that era of bipedal mode of movement as the most energy efficient.

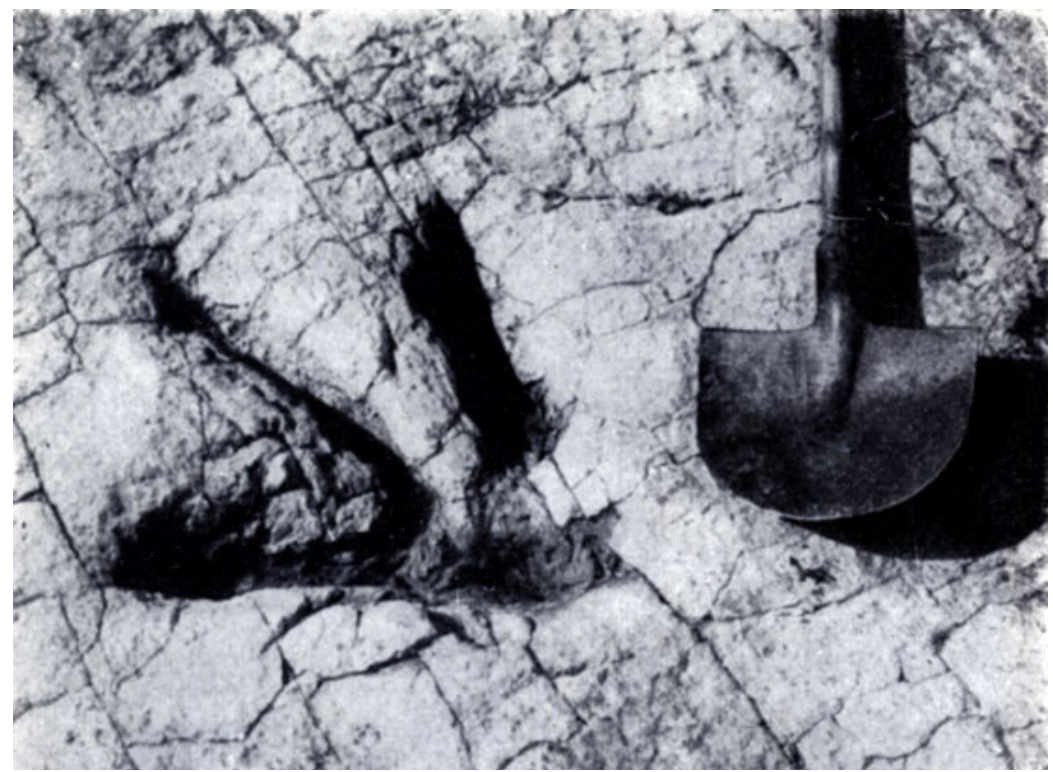

Figure 9. Print of the hind leg of a large predatory dinosaur from Mongolia (right-shovel for scale) [25]. 


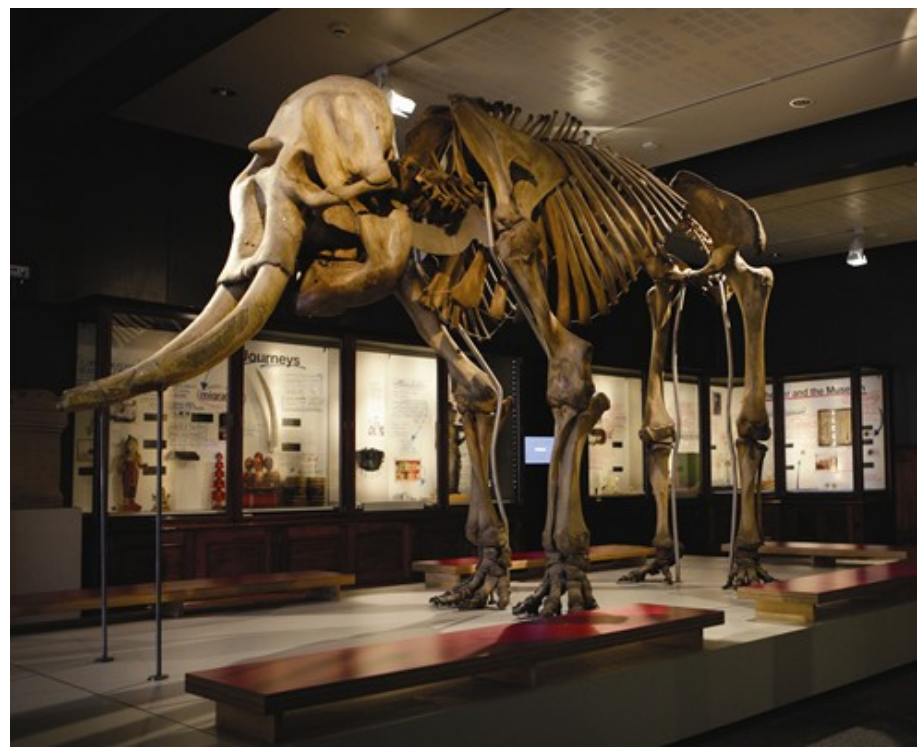

Figure 10. The skeleton of an Asian elephant (Elephas maximus) [26].

\section{Millions of Years Later}

The Gobi is the region with the most extreme climate on the globe (see [27]). Suffice it to say that the temperature amplitude of the surface layer of air here annually exceeds $80^{\circ}$. The duration of the frost-free period in the desert is only 120 - 150 days. In winter, its space is dominated by frosty little snow weather, close to subarctic. Minimum temperatures even in summer are below $15^{\circ}$ (Figure 11). Maximum temperatures in summer exceed $30^{\circ}$, in winter-do not reach the melting point.

Precipitation, falling mainly in the summer in the amount of up to $200 \mathrm{~mm}$, sometimes feed small temporary watercourses, lakes and swamps with salt water.

The severity of the climate of the Gobi Desert is explained by the fact that it occupies the inner region of Eurasia, where the situation of formation of continental air masses is created. In winter, Mongolia and neighboring territories become the center of a powerful Siberian anticyclone, which blocks the access of heat and moisture from the oceans and causes a deep cooling (Figure 12).

In other words, with the current geographical position of the region and the continent as a whole, the climate of the Gobi must be sharply continental, cold and dry.

Why was Mongolia very warm and humid during the Cretaceous period? In this case, it is impossible to talk about the influence of increased solar activity or greenhouse effect: there are no reliable data about them and-most importantly-the contrasts between the desert climate in the Holocene and the subtropical climate in the Mesozoic are too great. The answer to this question we will not find in the world literature, but there is reason to believe that the most important climate-forming factor 75 million years ago in this place and around the globe was a short path of heat and moisture transfer from the equator to the poles. 


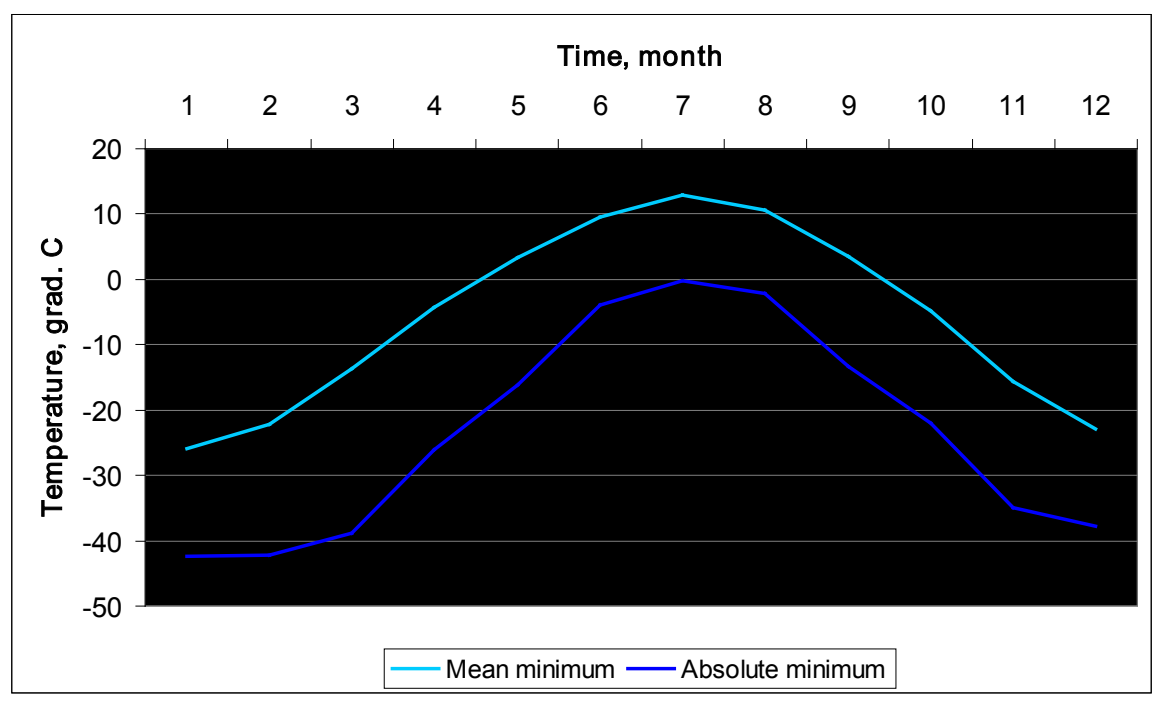

Figure 11. Average and absolute minimum temperatures in Mongolia (Ulaanbaatar station) [28].

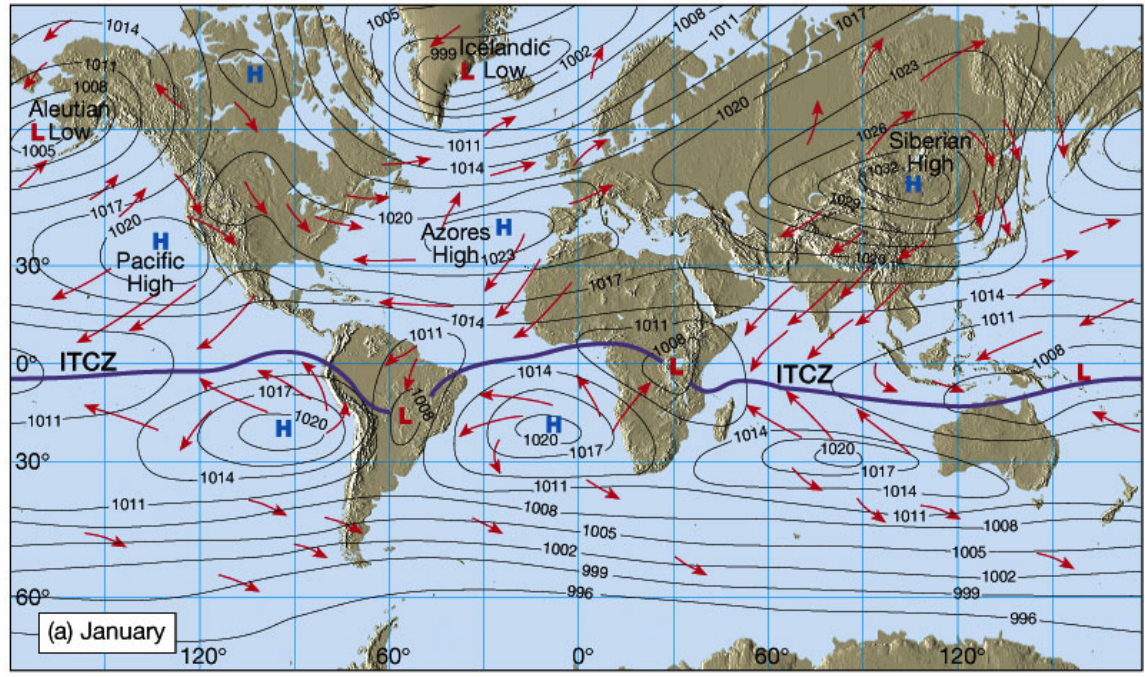

Figure 12. Siberian high in the general circulation of the atmosphere [29].

\section{Warm Climate with Two-Cell Atmospheric Circulation}

In the Quaternary, when the planet was periodically subjected to glaciation against the background of gradual cooling, in the atmosphere of its Northern and southern hemispheres, the transfer of heat and moisture from the Equatorial belt heated by sunlight to the temperate latitudes and poles is carried out by a system of three circulation cells (Figure 13).

Reserves of heat and moisture in the atmosphere are distributed by circulation cells over vast areas of continents and oceans, while in the Arctic and Antarctic there is a constant shortage of them due to the long distances of transportation. In the distant past, the situation was radically different. On a planet that was slightly larger than its modern core, there were only two atmospheric circulation cells functioning. The processes of heat and mass turnover on the Mesozoic planet 


\section{GLOBAL ATMOSPHERIC CIRCULATION}

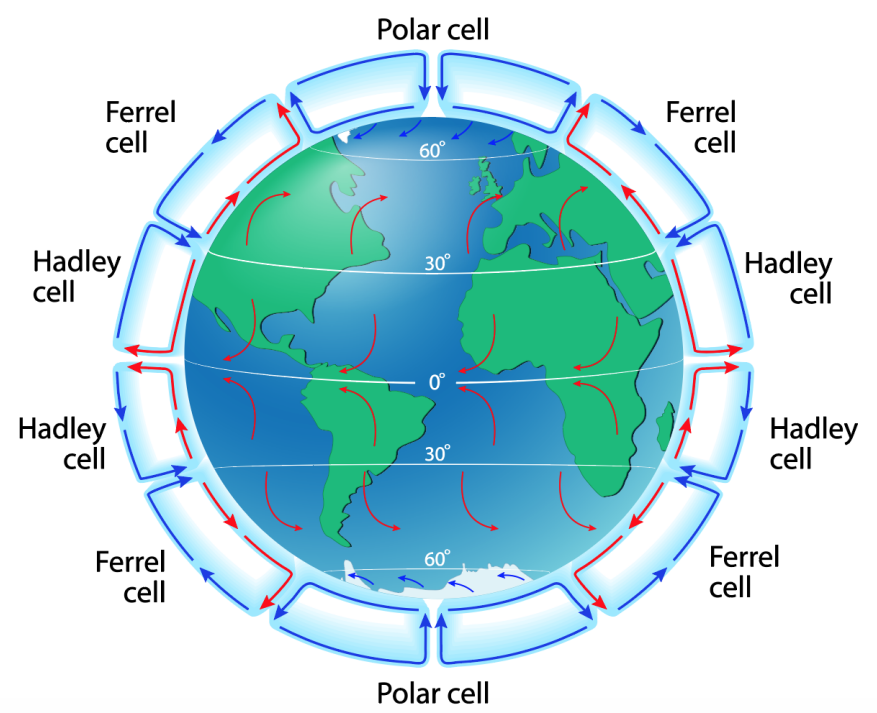

Figure 13. Three circulation cells in the atmosphere of modern Earth-Hadley, Ferrell and Polar [30].

were much more intense than now. In addition, due to the smaller diameter of the planet in winter at high angles of inclination of the sun's rays in the high latitudes received more energy and did not occur as large inter-latitude thermal contrasts.

To explain the paradox of the existence of two fundamentally different geographical systems in one place in the Mesozoic and Cenozoic can be the only way-movements in space on the surface of the expanding planet. Counterparts Goby landscape of Cretaceous age still exist, they are $20^{\circ}-30^{\circ}$ to the South of Mongolia.

\section{Conclusions}

The hypotheses dominating in modern natural science display separate fragments of the reality which are chosen from in advance known points of view illuminated by traditions. Facts that do not fit into the generally accepted schemes are left aside; empirical generalizations that contradict them are not taken into account.

If the chemical elements combine to form minerals, then the disclosure of the reasons that the new earth's crust covered most of the planet's surface in less than 200 million years, should be the very first task of geology.

If life is motion, then the phenomena of the birth of a vast mass of species of diverse animals with a bipedal way of moving and their complete extinction after hundreds of millions of years of prosperity must be one of the main subjects of interest in biology.

If the development of human civilization and the existence of all living organ- 
isms depend on the state of the environment, then the clarification of the circumstances of the shift from the Mesozoic heat to Quaternary ice should be among the most important problems of geography.

And if our Galaxy is a complete system, then astronomy should provide an understanding of the nature of the processes that can lead to a decrease and increase in the temperature of a cold celestial body at a rate completely incomparable with the pace of the star evolution.

The concept of the growth of the Earth is the real direction of the boundless interdisciplinary synthesis dreamed of by Alexander Humboldt and his followers throughout the world.

\section{Conflicts of Interest}

The author declares no conflicts of interest regarding the publication of this paper.

\section{References}

[1] Wegener, A.L. (1915) Die Entstehung der Kontinente und Ozeane. In: Sammlung Vieweg, Heft 23, Friedr. Vieweg \& Sohn, Braunschweig, 94S.

[2] Hilgenberg, O.C. (1933) Vom wachsenden Erdball. Giessmann \& Bartsch, Berlin, $56 \mathrm{~S}$.

[3] Carey, S.W. (1976) The Expanding Earth. Elsevier Scientific Publishing Co., Amsterdam, $488 \mathrm{p}$.

[4] Chudinov, Y.V. (2001) Education Concept of the Earth's Expansion Theory: Main Grounds, Paleomagnetic and Geodetic Evidences, Metallogenic Consequences. BRILL, 166 p.

[5] Blinov, V.F. (2003) Growing Earth: From Planets to Stars. URSS Editorial, Moscow, 271 p. (In Russian)

[6] Scalera, G. (2003) Why the Expanding Earth? INGV Publisher, 465 p.

[7] Kuznetsov, V.V. (2008) Introduction to the Physics of Hot Earth. Petropavlovsk-Kamchatsky, Kamgu, 367 p. (In Russian)

[8] Scalera, G., Boschi, E. and Cwojdziñski, S. (2011) The Earth Expansion Evidence-A Challenge for Geology, Geophysics and Astronomy. 2011 The Earth EXpansion Evidence, Erice, Sicily, Italy, 4-9 October 2011. https://www.researchgate.net/publication/270395664_The_Earth_Expansion_Evide nce_--_A_Challenge_for_Geology_Geophysics_and_Astronomy

[9] Maxlow, J. (2016) Modelling Modern Global Geodata on the Ancient Earth. https://www.dinox.org/publications/Maxlow2016-ModellingModernGlobalGeodata .pdf

[10] Retejum, A.J. (2018) The Growth of the Planet: The Experience of Empirical Generalization. The System “Planet Earth”, LENAND, Moscow, 35-57. (In Russian)

[11] Encyclopedia Britannica.

[12] Cretaceous Dinosaur Fossil Sites in the Mongolian Gobi (2014) UNESCO, World Heritage Centre. https://whc.unesco.org/en/tentativelists/5944/

[13] Benton, M.J. (2003) Age of Dinosaurs. Russia and Mongolia. Cambridge University Press, Cambridge, 740 p. 
[14] Mesozoic and Cenozoic Fauna and Biostratigraphy of Mongolia (1974) The Joint Soviet-Mongolian Paleontological Expedition. Transaction, 1, 380 p. (In Russian)

[15] Mesozoic and Cenozoic Faunas, Floras and Biostratigraphy of Mongolia (1977) The Joint Soviet-Mongolian Paleontological Expedition. Transaction, 4, 190 p. (In Russian)

[16] Paleobiogeography Problems of Asia (1986) The Joint Soviet-Mongolian Paleontological Expedition. Transaction, 29, 121 p. (In Russian)

[17] Mardfar, R.A. (2000) Relationship between Gravity and Evolution: The Theory of the Increasing of Gravity. Zeinab Tabriz, $124 \mathrm{p}$.

[18] Hurrell, S. (2011) Dinosaurs and the Expanding Earth. 3rd Edition, One off Publishing, $218 \mathrm{p}$.

[19] Dinosaurs and the Expanding Earth. https://www.dinox.org

[20] https://destepti.ro/dinozaurul-quaesitosaurus

[21] https://prehistorica.fandom.com/wiki/Nemegtosaurus

[22] The Orlov Paleontological Museum, Moscow. https://www.paleo.ru/museum/

[23] https://www.jackcentral.org/news/flagstaff-becomes-home-to--million-year-old-rar e-dinosaur/article_1d9d17fd-9f8b-59da-991f-32e4ac17d580.html

[24] Andrey Atuchin.

https://www.eartharchives.org/articles/deinocheirus-the-giant-hunchbacked-dinosa ur-with-terrifying-hands/

[25] Photo Namandortk. http://paleontologylib.ru/books/item/f00/s00/z0000001/st005.shtml

[26] The University of Manchester. http://bellevue.manchesterhistories.co.uk/maharajah-elephant

[27] Sabloff, P.L.W. (2011) Mapping Mongolia. Situating Mongolia in the World from Geologic Time to the Present. University of Pennsylvania Press, Philadelphia, PA, $304 \mathrm{p}$.

[28] http://www.pogodaiklimat.ru/monitor.php?id=44292

[29] Lutgens, K. and Tarbuck, E.J. (2001) The Atmosphere. 8th Edition, Prentice-Hall, Upper Saddle River, NJ, 512 p.

[30] https://www.internetgeography.net/topics/what-is-global-atmospheric-circulation/ 